Integritas 1.2 (Spring 2013), pp. 1-19.

doi: 10.6017/integritas.v1i2p1

\title{
Charism and the Literary Imagination
}

\section{Paul Mariani}

If by "charism" we mean a gift of God to be shared for the good of all, then Catholic universities ought to have particular interest in sharing a charism of Catholic literary imagination, as manifest in scores of works of artistic genius. The author reflects on his own intellectual and aesthetic formation, and laments that many institutions have displaced works of artistic genius and relegated them to an ancillary role. The author's response has been the development of a course that leads students through encounters with the Catholic sacramental imagination in the arts.

1. A statement as to the modern basis of poetic form (informal)

2. Read some illustrative verses

3. Spanish (Portuguese) and American-English. Our profitable interrelationship in developing a new poetic form: EXAMPLE_Lope de Vega vs. Shakespeare as a model (form) for America: What we might profit, etc.

Preamble: The difficulty is to keep such a talk as this informal.

After all, there is no great point at issue. We are here for the most part to look at each other, to recognize in each other - that curious complexity called a writer [Catholic Christian], to encourage and to learn. But most to try to find a means, through the art [charism] which we practice, to communicate with each other-for what may come of it.

\section{William Carlos Williams, Porto Rico Talk, April 16, 1941}

True painting is only the image of the perfection of God, a shadow of the pencil with which he paints, a melody, a striving after harmony.

Michelangelo

Paul Mariani is the University Professor of English and holds a chair position in the English Department at Boston College. He has published over 200 essays and reviews and is the author of seventeen books, including five biographies, seven volumes of poetry, and a spiritual memoir. His awards include a Guggenheim Foundation fellowship, a National Endowment for the Arts fellowship, and two fellowships from the National Endowment for the Humanities. He has lectured and read from his own work throughout the United States, as well as in Canada and Europe. His poems, which have been widely anthologized, have appeared in: Image, Poetry, America, Doubletake, The Kenyon Review, The Agni Review, New England Review, Crazyhorse, Southern Quarterly, The Hudson Review, Sundog, Tri-Quarterly, and The New Criterion. 


\section{Introduction}

The challenge here is to speak of a charism associated with the literary imagination and to speak of both charism and the literary imagination in a way that will be relevant to a twenty-first-century audience. The host here is understood to be the Catholic university, and so understanding the host-who sets the table and invites everyone to share at the table-will mean understanding who we are and then the wider international and diverse audience whom we are addressing.

What concrete suggestions can we offer to others

in terms of making the Catholic literary imagination available at our own Catholic universities?

First: How shall we understand the concept of charism? And is it the word we want in the context of a Catholic Roundtable such as this one?

Second: How do we define who we are as hosts?

Third: How do we define the guests— - the other-whom we primarily intend to address?

Fourth: How or in what ways shall we define the literary imagination and, more specifically, the literary imagination as it interacts with what we call the Catholic Christian tradition?

And fifth: Picking up on the idea of what Professor Aurelie Hagstrom calls the charism of "intellectual hospitality," what concrete suggestions can we offer to others in terms of making the Catholic literary imagination available at our own Catholic universities and colleges, and, by extension, to others who might also be interested in such a dialogic interchange - or who might benefit from being introduced, first of all, to the reality of such a tradition and then, beyond that, to the dynamic possibilities such a reality possesses?

As Professor Hagstrom reminds us, "when we welcome others, we welcome God, and in welcoming God we are participating in God's reconciling love for the world, manifest in God's Triune nature." By Triune nature, I am reminded of the eternal interchange between the Creator God (or Father), the Son, and the Holy Spirit, and of the Love manifested in that exchange. For myself, and for others here, I would think that welcoming the other, while at the same time maintaining our own distinctive personhood as the host, would be our special charism, our mission as a Catholic university. In short, I am speaking of that respectful, vibrant, ongoing exchange which brings us greater clarity and understanding of each other as we pursue the larger truths at the heart of the matter.

1. Aurelie Hagstrom, "The Role of Charism and Hospitality in the Academy" Integritas 1.1 (Spring 2013).
These are some of the questions which have daunted me ever since I walked into a world of theological and ontological speculation where even angels might fear to tread. To be frank, when I began teaching rhetoric and style and then literature and poetry, had no idea that I would someday be in dialogue with so many others-many of them theologians-concerning such fundamental issues as the various charisms that together make up the idea of a Catholic university. The fact is that the subject is so vast and so nuanced at the same time that it is important to pay close attention as we listen to each other wrestling with these issues.

\section{Charism and the University in Modernity}

Let's begin then by examining the idea of charism, one definition of which would seem to be a spiritual gift that helps define what one discerns one has been called to do in entering into the Mystery of Creation. "Everyone," St. Paul tells us, "has his or her proper gift [charisma] from God; one after this manner, and another after that" (I Corinthians 7:7) Charisma is also the theological term for denoting extraordinary graces given by the Holy Spirit to individual Christians for the good of others. Let's repeat that: a special gift given by the Holy Spirit to an individual to be used for the good of others. St. Paul also speaks of the necessity of saying what one feels moved to say, and then of having two or three or more others discern what has been said so that what the speaker has shared should have

Our shared mission means understanding how each of our voices shares in and adds to the available stock

of what we see as the central mystery of existence.

the greatest salutary effect on the rest of the community (I Corinthians I4:27)

And since I know that I do not possess the special intellectual charism, say, of St. Thomas Aquinas, to synthesize a reality I only dimly understand, being all too often another conflicted citizen in our own postmodern, perhaps post-everything historical moment, I will have to examine the question of the Catholic literary imagination in a way that makes sense to me, and I hope will resonate with many of you as well. And because what all of us assembled here this weekend share is our Catholic faith andby extension - the desire to share the knowledge and experience imbued by that faith tradition, we see the issues involved through a staggering multitude of intellectual and personal lenses, each having its own particular language, a language which in large part also identifies who we are in our role as hosts.

We can begin, then, by acknowledging a shared sense of what has brought us together for this series of Roundtable discussions, where various theologians, political scientists biologists, physicists, economists, psychologists, historians, and those involved in lit erature enjoy a shared sense of understanding, and by extension, of mission. What is 
involved in that endeavor, it seems, is the willingness to listen to the other, but also to exchange, clarify, and, yes, expand what we understand to be our own special charisms. And that means understanding how each of our voices shares in and adds to the available stock of what we see as the central mystery of existence. For us, this will mean a continued prayerful discernment to better understand the gifts we have been given and, because that is what Love does, to share those gifts gladly with the others at our table.

I see myself as fully engaged in the creative work of the imagination as a poet, a biographer, a memoirist, a critic, and a scholar, as well as someone who has been teaching at the university level for the past fifty years. I was first introduced to the Catholic literary imagination as a young man. After years in a Catholic parish and high school, I spent four years, between I958 and I962, at Manhattan College in the Riverdale section of the Bronx, a Catholic college run by the LaSalle Christian Brothers. It was here that, after first considering majoring in psychology and then in Medieval philosophy, I opted at the last moment for English and American Studies, my real loves, taking a total of ${ }_{15} 6$ credits in theology and the humanities, including Latin and Greek. I simply could not get enough of the knowledge that was being offered me, and I spent every extra dollar I had on cheap paperbacks of everything from Plato and Aristotle to Piers Plowman and the Church fathers.

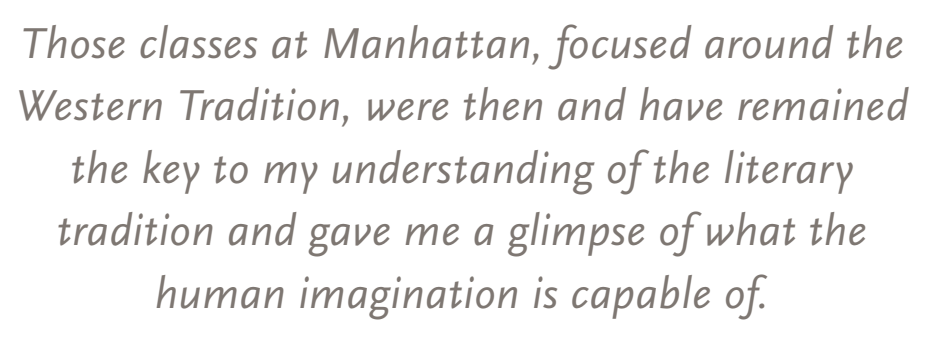

What Manhattan College gave me was a knowledge and a freedom which my parents, products of the Depression, never had, and which I vowed even then to pass on to others-a visionary synthesis of the Great Books knowledge that I have seen fade and crumble with time, to be replaced too often with the chitter of critical languages which usually enjoy a shelf life of a dozen or so years before they themselves are morphed into the latest and greatest new knowledge ever to be packaged.

What I was offered fifty years ago was four years of cornerstone courses in the Western tradition, beginning with the Egyptians and Babylonians, on through the Greeks and Romans, then on to the Middle Ages, the Renaissance, the Reformation and Counter-Reformation, the Rationalists of the Enlightenment, European Romanticism, the American Experience, and the twentieth century, including World Wars I and II.

Each semester we took four related courses in philosophy, history, literature, and the arts (music, architecture, sculpture, and painting). Nights I worked at my father's gas station, pumping gas, and when that failed, I shredded highly classified government documents in a locked room in some apartment complex, or stacked shelves in two branches of the A\&P from six to eleven, after which I listened to Mozart, Beethoven, and Rimsky-Korsakov on an old $78 \mathrm{rpm}$ Victrola. Those classes at Manhattan, focused around the Western Tradition, were then and have remained the key to my understanding of the literary tradition and-as if I had looked up at the stars without fully understanding it at the time-gave me a glimpse of what the human imagination is capable of

After that I went on to Colgate University for my master's in English, taking courses in everything from the Jacobean playwrights to Edmund Burke and Gibbon and Jane Austen, as well as Ralph Waldo Emerson, Thomas Carlyle, E. A. Robinson, and Robert Frost, and meeting writers as diverse as Robert Creeley and Michael Harper and Isaac Bashevis Singer. And then four years at the Graduate Center of the City University, where I found my ideal mentor in Allen Mandelbaum, translator of Virgil and Dante and Ovid and Homer, as well as of Ungaretti, Montale, Quasimodo, and Giudici.

Of course, there were and are and always will be gaps in one's education, no matter how much one tries to fill them in, for each subject as it is examined seems to widen and deepen into a galaxy of its own, and, inevitably, within that galaxy, other galaxies begin to reveal themselves. I know too that what I constructed over those four years was only a skein of what constitutes the ever-expanding realities of our multivalent worlds. For one thing, as the Ig6os made clearer as they unfolded, I came to see how relatively few women had been incorporated into the Western tradition I'd been offered at an all-men's college, as well as how little there was of Asian, Middle Eastern, African, Latin American, as well as African-American, Asian-American, and Hispanic-American history and culture included in my courses. The result was that not fewer and fewer, but more and more questions arose over the years as to how these multivalent voices were to be incorporated into a core curriculum that by most standards was already overflowing. New balances would have to be created, new knowledges, new thresholds, new anatomies discovered.

Less than a decade after I graduated from Manhattan, the Great Books Core there had been revised, redirected, deboned, filleted, and abandoned. I learned later-being too busy at the time- - that most students felt they'd been inundated with too many oneand two- and three-credit courses in order to include St. Anselm and Abelard, or Bach and Mozart, or Fra Angelico or the Post-Impressionists. Then, too, there was the question of relevance, which bubbled to the surface or came as the necessary aftershocks of America's involvement in Vietnam and the civil rights movement and women's rights.

"Freedom" to choose one's electives, the freedom to express oneself, the distrust of anyone over thirty: all of these almost overnight became the new norm, though-since I'd already left the safety of the academic airport a decade earlier, even as it was being encircled as Dien Bien Phu and Khe San and Columbia University and, later, Saigon would be surrounded-I continued with my pre-I962 dream of filling in the gaps in my education with graduate studies and teaching and my own scholarship for the next six or more decades. 
"Let a thousand flowers bloom," I remember one of my white-haired senior colleagues at the University of Massachusetts mumbling over and over back in the I97os, as the old core unwound and was replaced with newer, more flexible cores. Of course, when he said it, it was with a mixture of disdain and despair as even the basic Core that had replaced the earlier, more detailed one came under withering fire and dismemberment, again to be replaced by exemptions in the humanities and English for football players and other athletic icons and a barrage of electives for everyone that took the place of a center which no longer seemed to be able to hold itself together.

There were, of course, many reasons for this turnaround, both by the students, for whom the new chant was relevance, relevance, and more relevance, and by the professors themselves, who were eager to teach their specialties wherever possible, especially in an age of "publish or perish." Another catchword then, as now, was diversity, or the necessary inclusion of many of those voices which had until then been excluded or overlooked in the cultural demographics of the time. Some experiments which incorporated the new voices fared well and grew in a time of radical experimentation, while others faded or overnight were dropped from the curriculum altogether, among the casualties being not only the new experiments but many of the traditional courses as well.

What I have found, ironically, among many Catholic institutions of higher learning is that, while the campuses indeed invite the other with enthusiasm to sit at the table, the table itself, as far as the Catholic Christian literary tradition goes, has often been stripped almost bare.

For thirty-two years, from I9 68 until 2000, I taught at the University of Massachusetts, and then, approaching my sixtieth birthday, I decided that if change was in the landscape, I was going to have to act, and soon. And so, after an eight-day spring retreat with the Jesuits in March of I999, I decided—or God decided for me-that I should teach at Boston College. Which made sense, of course, for though I had never been on the Boston College campus, this change would enable me to work within a viable Catholic and Jesuit literary tradition.

And while I have seen many strong signs of a Catholic charism at Boston College, especially in the fields of theology, philosophy, and history - to name just three-I did not find it flourishing in my own field of English literature. Perhaps I was naive to expect it, as if I had thought I might find Fr. Bing Crosby walking across campus and singing to himself while the Bells of St. Mary's chimed in the spring air.

What I have found, ironically, among many Catholic institutions of higher learning is that, while the campuses indeed invite the other with enthusiasm to sit at the table, the table itself, as far as the Catholic Christian literary tradition goes, has often been stripped almost bare, and the idea of a Catholic Christian literary imagination relegated more and more to an ancillary position, until it seems to have virtually disappeared. Which is too bad, really, because topics like the sacramental understanding of the world in terms of beauty and justice are surely worthy of our consideration, especially in a time when images of death and broken bodies and random acts of violence inundate our music and dance halls and movie theaters and television screens so that they have become the new normal, where ideas like mercy and love and forgiveness and commitment to the other often give rise to feelings of embarrassment.

So, while a university like Boston College has certainly been willing to host the stranger, the host itself seems to have become the stranger, too often marginalized or at best barely tolerated, or held in suspicion or simply ignored as long as the host's largesse continues to flow. "One cannot (or should not) ignore those who profess a faith different from Catholic Christianity," Chester Gillis rightly reminds us. "Welcoming and getting to know the religiously other while in college prepares Catholic students for the world that they will enter upon graduation." And Catholic universities, especially Jesuit centers of higher learning, have earned a solid reputation for hosting and welcoming students and faculty from many religious and even non-religious traditions by encouraging and providing "opportunities for interreligious dialogue."

And that is true enough. But for me the problem remains that, whereas non-Catholic and secular universities have often hosted a Catholic Studies program on their campus, this is not always the case at many of our Catholic universities.

Why is this? And why has this been allowed to happen?

\section{Catholicism and the Literary Imagination}

Most members of a university would be willing to admit that there's a profound rich ness to the Catholic Artistic and Literary Tradition. Consider, for example, on the popular level, Fr. Robert Barron's engrossing video series, Catholicism. But so much of that Catholic literary tradition goes untapped here at our own Catholic universities. Even in time of multi pluralisms, this tradition, which has undergirded our Catholic universities for seven hundred years, is frequently ignored, even as an option or elective to be offered to our students.

Is it because this extraordinary tradition is too often taken as an historical museum piece or perhaps even as an embarrassment? Have we indeed moved into a post-Catholic-university phase where the mission of the Catholic university to support, on some level, a Catholic Christian literary tradition is simply ignored? When I look at our own Catholic Studies program here, I see that of the half dozen or so courses in literature with a Catholic literary component offered over the past decade, only one is still offered, and that of the four professors of English who taught these courses, two are retired, one is deceased, and one is left like Ishmael to tell the story.

2. Chester Gillis, "Welcoming the Religiously Other to a Catholic University," Integritas 1.3 (Spring 2013). 
Are not Paul and Augustine and Dante and John of the Cross, Hildegard of Bingen, Teresa of Avila, and Thérèse of Lisieux - all participants in a grand tradition and an openended experiment-worthy of our study and of passing their knowledge and wisdom on to our students?

From what I have been able to ascertain, Georgetown University seems to have fared better, and still maintains what looks like a viable Catholic Studies program, though there is only one Catholic Studies course cross-listed with English, and that is a semester-long study of Eliot's The Waste Land. There are, in addition, two other courses in the Literary Imagination: one on Shusaku Endo, offered by the Department of Japanese Studies, and a course in the philosophy department on Dante and the Christian Imagination. The University of St. Thomas in Houston has offered a Lenten series on the Catholic Imagination that looks very promising. This year's lectures, for example, included Thomas More's Utopia, Annie Dillard's Holy the Firm, and John Henry Newman's Cor ad cor loquitur ("Heart Speaks to Heart"), along with the Conversion of the Imagination, Catholic Anthropology and Ethics in Tolkien's Middle-earth, the Vita Contemplativa of St. Teresa of Avila and St. John of the Cross, and-finally-G.K. Chesterton and the Tower of Babel.

The question, then, seems to be this: Are not Paul and Augustine and Dante and John of the Cross, Hildegard of Bingen, Teresa of Avila, and Thérèse of Lisieux-all participants in a grand tradition and an open-ended experiment-worthy of our study and of passing their knowledge and wisdom on to our students? Add to this mix Chaucer and Shakespeare, St. Robert Southwell, Richard Crashaw, Cervantes and Herbert and Hopkins, T. S. Eliot and David Jones and Charles Péguy, Chesterton and Graham Greene and Flannery O'Connor, along with Bach and Palestrina, DaVinci, Michelangelo, and Caravaggio. Then consider the multitude of writers from Hardy and Yeats and Pound and Hart Crane and William Carlos Williams and Faulkner and Hemingway on to Willa Cather and William Kennedy and Cormac McCarthy, Kazantzakis, Tolstoy, Dostoevsky, Sartre, Camus, Simon Weil, and so many others who have borrowed from or argued for or against this tradition in their own work. Looked at in this light, is this not a great treasure trove that, if not honored, has at least been ransacked, the stained glass smashed and the great murals ripped from their walls and only the shards left behind? But what bright shards they are!

Perhaps it is time once again to examine our role in presenting the beauty and electric force of the very tradition which has served as the foundation of what we profess to teach. Perhaps it is time not only to consider the question of social justice, which would surely have a strong following, but to consider as well the question of beauty, the very splendors of nature seen through a sacramental lens: the beauty which Péguy and Rilke and Hopkins and David Jones and W. H. Auden and Flannery O'Connor and T. S. Elio and Thomas Merton and Hans Urs von Balthasar, among others, have shown us.

Consider this poem by Hopkins. A curtal sonnet, a sonnet distilled from its normal form of fourteen lines to ten and a half lines, a complete microcosm, a prayer, really, which looks hard at the world and then gives beauty back to God. "Glory be to God for dappled things-," the poem begins, and then shows us what a dappled world looks like.

Glory be to God for dappled things-

For skies of couple-colour as a brinded cow;

For rose-moles all in stipple upon trout that swim;

Fresh-firecoal chestnut-falls; finches' wings;

Landscape plotted and pieced—fold, fallow, and plough;

And áll trádes, their gear and tackle and trim.

All things counter, original, spare, strange;

Whatever is fickle, freckled (who knows how?)

With swift, slow; sweet, sour; adazzle, dim

He fathers-forth whose beauty is past change:

Praise him.

And what if? What if we could find a place on our Catholic campuses to offer that praise even as the Eucharist is offered up each day in our campus chapels? A single place, a room, where we could come together to study such poems and narratives, where it would be possible to consider not only the Good Fridays of our existence, but the Eastering at the heart of our long tradition as well?

In the years since I've been at Boston College, I have brought in aspects of the Catholic Literary Imagination for the simple reason that those images keep coming up again and again of their own accord. So, for example, if I teach Yeats's "The Second Coming," written in I9I9 in the midst of the Irish Troubles, how can I avoid talking about the idea of Christ's Second Coming, along with the images of the mystery of the Sphinx and the concept of the Jungian Spiritus Mundi and how Yeats has reworked that material here, where Christian teleology and hope give way to the idea of the unending desert-like eternal return?

Surely some revelation is at hand;

Surely the Second Coming is at hand.

The Second Coming! Hardly are those words out

When a vast image out of Spiritus Mundi

Troubles my sight: a waste of desert sand;

A shape with lion body and the head of a man,

A gaze blank and pitiless as the sun, 
Is moving its slow thighs, while all about it

Wind shadows of the indignant desert birds.

The darkness drops again but now I know

That twenty centuries of stony sleep

Were vexed to nightmare by a rocking cradle,

And what rough beast, its hour come round at last,

Slouches towards Bethlehem to be born?

Or Kenneth Rexroth, trying to explain what he sees as so special about the doctor/ poet from the Passaic section of New Jersey, William Carlos Williams.

From "A Letter to William Carlos Williams"

Remember years ago, when I told you you were the first Great Franciscan poet since The Middle Ages? I disturbed The even tenor of dinner. Your wife thought I was crazy. It's true, though. And you're "pure," too,

A real classic, though not loud About it...

..............

It's a wonderful quiet

You have, a way of keeping

Still about the world, and its

Dirty rivers, and garbage cans,

Red wheelbarrows glazed with rain,

Cold plums stolen from the icebox,

And Queen Anne's lace, and day's

eyes,

And leaf buds bursting over

Muddy roads, and splotched bellies

With babies in them ..

....................

Nowadays, when the press reels

With chatterboxes, you keep still,

Each year a sheaf of stillness,

Poems that have nothing to say
... The day will come

When a young woman will walk

By the lucid Williams River,

Where it flows through an idyllic

News from Nowhere sort of landscape,

And she will say to her children,

“Isn't it beautiful? It

Is named after a man who

Walked here once when it was called

The Passaic, and was filthy

With the poisonous excrements

Of sick men and factories.

He was a great man. He knew

It was beautiful then, although

Nobody else did, back there

In the Dark Ages. And the

Beautiful river he saw

Still flows in his veins, as it

Does in ours, and flows in our eyes,

And flows in time, and makes us

Part of it, and part of him.

That, children, is what is called

A sacramental relationship.

And that is what a poet

Is, children, one who creates

Sacramental relationships

That last always."
It's something of this deeper, sacramental understanding of our world which I'd love to see brought back into our classroom on a regular basis. And with this in mind, I've tried to create at least one course which I am relieved to report has filled up whenever I've offered it, and I find myself trying to offer it now each year. It's called God and the Imagination, and it should be around at least for the next couple of years, when I hope it or something like it will remain available for our students.

\section{It's something of this deeper, sacramental} understanding of our world which l'd love to see brought back into our classroom on a regular basis.

Here is a brief summary of the course as it's now taught. It's divided into three parts, following the Spiritual Exercises and Dante's Divine Comedy. First come the Hell Variations, or the going down ever more deeply, where we focus on the opening and closing cantos of the Inferno. Luca Signorelli's images in the Cathedral at Orvieto provide vivid images of the end time and of the Anti-Christ, but so too do images of the trench warfare-those Malebolges of Dante's-and images of the Holocaust and the massive bombings of population centers from Guernica up through Hiroshima and beyond. Among the poems we look at are Wilfred Owen's "Strange Meeting” and Isaac Rosenberg's "Break of Day in the Trenches," as well as Anthony Hecht's incredibly dark poem "More Light! More Light!"

From there we look at Emily Dickinson's "I heard a fly buzz when I died," Thomas Hardy's “The Convergence of the Twain," and Philip Larkin's "Aubade," journeys which stare into the imagined Abyss. And from there we look at the post-apocalyptic journey in Cormac McCarthy's The Road, to see how a father tries to provide for his young son even when all hope seems lost.

Then it's on to Fr. Hopkins's Sonnets of Desolation \& Recovery: "Spelt from Sybil's Leaves," "To seem the stranger," "I wake and feel," "No worst, there is none," and "Carrion Comfort" read in conjunction with Psalm 22, Christ's cry from the cross. And then it's T. S. Eliot's The Waste Land and the post-World War I landscape, as pockmarked and bomb-blasted as the landscape of the soul in a time of travail. Dante's selva oscura his dark woods.

Then, on the upslope of hope, it's on to the Purgatorio, or the Long Journey of the Pilgrim, focusing on six of Dante's Cantos, then looking at Robert Lowell's renderings of Dante's last-breath-penitent on the battlefield, as well as parts of Hopkins's The Wreck of the Deutschland and the cry of the nun in the midst of the another shipwreck. Then it's Marie Howe's “The Star Market," and the presence of Christ in the humblest of places. Next comes William Kennedy's Ironweed and the redemptive journey back home, 
in this case occurring during the triduum of Halloween, All Saints, and All Souls in Depression-ridden Albany, I938. We also look at Eliot's aptly named purgatorial pieces, "Journey of the Magi" and "Ash Wednesday."

Then it's on to the journals of Thomas Merton from the late i93os until his death by electrocution in the fall of 1968 while attending an international conference of monks in Bangkok. And then on to Merton's contemporary, Flannery O'Connor, with such classic short stories as "A Good Man Is Hard to Find," "The River," "The Life You Save May Be Your Own," "A Stroke of Good Fortune," "The Artificial Nigger," "Good Country People," and ending with "The Displaced Person." And from there we move on to John Berryman, with ten of his bleakest Dream Songs, in which he questions the ways of God and the ways of man, before we move to the humbler, searching sequence he wrote while in recovery, his "Eleven Addresses to the Lord."

Finally, it's on to the Paradiso, glimpses of heaven and the possibilities of transfigurative change. Here we look at Hopkins's sonnets of celebration, including "God's Grandeur," "As kingfishers catch fire," "The Windhover," "Pied Beauty," and "Hurrahing in Harvest," and then look at Hopkins's poems of spiritual recovery in "That Nature is a Heraclitean Fire and the Comfort of the Resurrection" and the message of his last, very quiet poem, “To R. B." Then it's on to Eliot's final Quartet: “Little Gidding," a poem of profound hope composed in the wake of the German bombings of London in I940 where, in spite of everything, he calls to mind The Cloud of Unknowing and Julian of Norwich's mantra that "All shall be well, and all manner of things shall be well."

Then on to four of Dante's Paradiso Cantos with Beatrice and Mary and Benedict and the amassing of the whole harmonium in the glimpse of the human face at the center of God's Love. Then on to the poetry of some contemporary American poets in the Catholic tradition, including Denise Levertov, Franz Wright, Scott Cairns, and Mary Karr, as well as poems by Robert Hayden, Lucille Clifton, Anne Sexton, Yeats, William Carlos Williams, and Wallace Stevens, that solitary agnostic whose journey led at the end to his conversion to the Church, and whose biography I am now in the midst (and mist) of writing.

Undoubtedly there are many other voices which might be included in such a course: Augustine's Confessions, the Anglo-Saxon Beowulf, Langland, Caedmon, Chaucer, Chidiock Tichborn, Shakespeare, Catherine of Siena, the Metaphysical poets, including Donne and Herbert, then Dryden and Pope, Dostoevsky's Crime and Punishment and The Brothers Karamazov, Ernest Dowson, Paul Claudel, Charles Péguy, Jacques Maritain, Georges Bernanos, Pascal's Pensées, Joseph Conrad's Heart of Darkness, Graham Greene's The Power and the Glory, Walter Miller's A Canticle for Leibowitz, Ron Hansen's Mariette in Ecstasy and Exiles, Annie Dillard's Pilgrim at Tinker Creek, Patricia Hampl's Virgin Time, Alice McDermott's Charming Billy, the novels of Endo Shusaku, Francis Thompson's “The Hound of Heaven," Christina Rossetti, Oscar Wilde's The Ballad of Reading Gaol, David Jones, Les Murray, Geoffrey Hill, and Walker Percy.

God and the Imagination is something I've cobbled together as much out of a sense of what I owe the students and the administration of Boston College as it is a sense of frustration with myself and with the academic world in which I often find myself. What is troubling for me is that I see little in the way of a renewal of the role of the Catholic Literary Imagination except where the administration can address the question. And I have found that the administration here at Boston College does care, and is serious about its mission for renewal. Has it not, in fact, brought us together here to talk about recharging the charisms which have been part of our great Catholic tradition for centuries, and which may, if they are not safeguarded, be swept away with the tides and sands of time?

There is undoubtedly a rich heritage in the Catholic Literary imagination, not only in the sense of a call for social justice-for that seems to be something that many of our professors and staff are aware of-but also in the sense of a particular understanding of the sacramental vision of the world. I mean the fact of the Incarnation and what that signifies for our understanding of beauty and peace and understanding in the world-that is, of how God suffuses the world and everything in it.

Or, as Flannery O'Connor says in "A Good Man Is Hard to Find," that, as the family who will die that very day leaves their home in rural Georgia, and though only the narrator seems to notice, the trees themselves "were full of silver-white sunlight and the meanes of them sparkled." And if the meanest of the trees sparkle, so too does the criminal called the Misfit reveal a sparkle of goodness before he kills the grandmother who has reached out to him, even in the midst of her agony recognizing him as one of her children.

"If you came this way," T. S. Eliot tells us in the last of his Four Quartets,

Taking the route you would be likely to take

From the place you would be likely to come from ...

If you came at night like a broken king,

If you came by day not knowing what you came for,

It would be the same, when you leave the rough road

And turn behind the pig-sty to the dull facade

And the tombstone. And what you thought you came for

Is only a shell, a husk of meaning

From which the purpose breaks only when it is fulfilled If at all.

Or Hopkins, at the close of his sonnet "The Windhover," watching the majestic hawk buckle and plunge to the earth, like the God/man Christ buckling on the cross in the final sacrifice of himself for others. Only then, Hopkins realizes, having made the Long Retreat, ${ }^{3}$ only then does it happen. For only in the breaking of oneself does the dying fire flame out like shining from shook foil, or the kingfisher catch fire, or the dragonfly draw flame:

3. This is the thirty-day retreat following the Spiritual Exercises of St. Ignatius Loyola, an exercise made by many thousands of individuals over the past half-century. 
AND the fire that breaks from thee then, a billion

Times told lovelier, more dangerous, O my chevalier!

No wonder of it: shéer plód makes plough down sillion

Shine, and blue-bleak embers, ah my dear,

Fall, gall themselves, and gash gold-vermillion.

\section{God's Grandeur}

The world is charged with the grandeur of God.

It will flame out, like shining from shook foil;

It gathers to a greatness, like the ooze of oil

Crushed. Why do men then now not reck his rod?

Generations have trod, have trod, have trod;

And all is seared with trade; bleared, smeared with toil;

And wears man's smudge and shares man's smell: the soil

Is bare now, nor can foot feel, being shod.

And for all this, nature is never spent;

There lives the dearest freshness deep down things;

And though the last lights off the black West went

Oh, morning, at the brown brink eastward, springs -

Because the Holy Ghost over the bent

World broods with warm breast and with ah! bright wings.

What the Catholic sacramental perspective teaches us is that the meanest thing carries within it something of inestimable worth, an inscape which gives to that particular thing a deeper value, which we are invited to discover and-when that value has been discovered - to give back that beauty to God by praising the Creator. Saint Francis and Saint Ignatius acknowledged as much, as did Hopkins and O'Connor and Walker Percy and Ron Hansen and so many others.

Catholicism carries within it an incredibly rich tradition, one shaped by two thousand years where the human imagination has been shaped by and in turn has helped shape Christianity and-by extension-various cultures as we have come not only to know the Mystery but to inhabit it as well. In truth it has informed, reformed, and transformed what we read and see and understand about the entire spectrum of humanity. I am reminded of Hopkins, that extraordinary poet who belongs to a great Jesuit tradition of charisms freely and often unexpectedly given. If the world is charged with the grandeur of God, so too is the Catholic imagination, with its emphasis on a God-saturated, God-centered world with its long tradition of sacramental beauty.

There it is, then: the Catholic Literary Imagination, each individual contribution to it like a tessera contributing to the larger edifice which has housed and still houses a rich sacramentality, and where a living voice still speaks, and where the Word still dwells. For one of the stunning gifts of that charism is that it continues to well up and give of itself endlessly.

"Cosi la mente mia, tutta sospesa," Dante reports back to us in the final lines of the Paradiso, after having gazed on the face of the Divine, "mirava fissa, immobile e attenta, e sempre di mirar faceasi accesa." Here it is, then, a glimpse into the Eternal which Dante the pilgrim, after a lifetime's searching, seems finally to have been granted:

So was my mind-completely rapt, intent,

steadfast, and motionless-gazing; and it

grew ever more enkindled as it watched.

Whoever sees that Light is soon made such

that it would be impossible for him

to set that Light aside for other sight. ...

What little I recall is to be told,

from this point on, in words more weak than those

of one whose infant tongue still bathes at the breast. ...

What he sees is the Three-in-One, the Godhead, the Trinity: three circles, each a different prismatic color, but all partaking in the whiteness of the Eternal Godhead, and which he now addresses:

Eternal Light, You only dwell within

Yourself, and only You know You; Self-knowing,

Self-known, You love and smile upon Yourself!

That circle-which, begotten so, appeared

in You as light reflected-when my eyes

had watched it with attention for some time,

within itself and colored like itself,

to me seemed painted with our effigy,

so that my sight was set on it completely. . .

I wished to see

the way in which our human effigy

suited the circle and found place in it-

and my own wings were far too weak for that.

But then my mind was struck by light that flashed

and, with this light, received what it had asked. 
Here force failed my high fantasy; but my

desire and will were moved already—like

a wheel revolving uniformly-by

the Love that moves the sun and the other stars. ${ }^{4}$

A lifetime's searching by the Catholic/Christian imagination is to be found in these lines. Wouldn't it be something to be able to offer that radiant tradition a place on the campuses of the very universities to which it has given its life and voice over the centuries? If its offspring and shoots have been dispersed all over the world now, isn't it time that we returned to the matrix, to the heart of the matter, where that unique perspective on the world might be given a room of its own, in the company of its sisters in theology and philosophy and art and music and architecture and history and so many other areas of study?

In a time of cultural diversity, which we continue to welcome and host, might there not at least be a place at the table for the host where the charism of the Catholic sacramental literary imagination might be acknowledged, celebrated, and shared with others as part of the necessary, never-ending dialogue between the host and the multitude of guests welcomed at that table?

Sources cited (by genre, with some representative works)

\section{Literature}

Jane Austen, Pride and Prejudice and Sense and Sensibility

Georges Bernanos, Diary of a Country Priest and Under the Sun of Satan Beowulf

Albert Camus, The Stranger and The Plague

Willa Cather, O Pioneers! and MY Ántonia

Miguel de Cervantes, Don Quixote

Geoffrey Chaucer, Canterbury Tales

G. K. Chesterton, The Man Who Was Thursday and Orthodoxy

Joseph Conrad, Heart of Darkness and Lord Jim

Annie Dillard, Holy the Firm and Pilgrim at Tinker Creek

Fyodor Dostoevsky, The Brothers Karamazov and Crime and Punishment

Shusaku Endo, Silence and Deep River

William Faulkner, The Sound and the Fury and Absalom, Absalom!

Graham Greene, End of the Affair and The Power and the Glory

Patricia Hampl, Virgin Time and The Florist's Daughter

Ron Hansen, Mariette in Ecstasy and Exiles

Thomas Hardy, Tess of the d'Urbervilles, Jude the Obscure, and "Convergence of the Twain"

4. Dante, Paradiso, canto XXXIII, trans. Allen Mandelbaum (New York: Bantam, 1986).
Ernest Hemingway, A Farewell to Arms and For Whom the Bell Tolls

Nikos Kazantzakis, Zorba the Greek and The Last Temptation of Christ

William Kennedy, Ironweed and O Albany!

Cormac McCarthy, The Road and No Country for Old Men

Alice McDermott, Charming Billy and After This

Walter Miller, A Canticle for Leibowitz

Flannery O'Connor, "A Good Man is Hard to Find," "The River," "The Life You Save

May be Your Own," "A Stroke of Good Fortune," "The Artificial Nigger," "Good

Country People," and "The Displaced Person"

Walker Percy, The Moviegoer and Love in the Ruins

Jean-Paul Sartre, No Exit and Nausea

Isaac Bashevis Singer, Gimpel the Fool and Yentl

Leo Tolstoy, War and Peace and Anna Karenina

2. Poetry

Dante Alighieri, The Divine Comedy

W. H. Auden, "The Shield of Achilles" and The Age of Anxiety

John Berryman, The Dream Songs and Eleven Addresses to the Lord Caedmon, "Hymn" Scott Cairns, Short Trip to the Edge: Where Earth Meets Heaven-A Pilgrimage and Recovered Body

Paul Claudel, Jeanne d'Arc au Bûcher and Cinq Grandes Odes

Lucille Clifton, Blessing the Boats and Two-Headed Woman

Hart Crane, "The Broken Tower" and The Bridge

Richard Crashaw, "To the Name above every Name, the Name of Jesus" and "Christ Crucified"

Robert Creeley, Collected Poems and Life \& Death

Emily Dickinson, "I heard a fly buzz when I died" and "This world is not conclusion" John Donne, Divine Sonnets and Meditations

Ernest Dowson, Verses and Decorations

John Dryden, Annus Mirabilis and The Hind and the Panther

Robert Frost, Collected Poems and A Witness Tree

T. S. Eliot, The Waste Land, Journey of the Magi, Ash Wednesday, and Little Gidding (in Four Quartets)

Giovanni Giudici, L'educazione cattolica and I versi della vita

Michael Harper, Dear John, Dear Coltrane, and Images of Kin

Robert Hayden, Heart-Shape in the Dust and A Ballad of Remembrance

Anthony Hecht, "More Light! More Light!" (in The Hard Hours) and Flight Among the Tombs

George Herbert, The Temple: Sacred poems and private ejaculations

Geoffrey Hill, Mercian Hymns and Broken Hierarchies

Gerard Manley Hopkins, The Wreck of the Deutschland, "God's Grandeur," "As king. 
fishers catch fire," “The Windhover," "Pied Beauty," "Hurrahing in Harvest," "That Nature is a Heraclitean Fire and of the Comfort of the Resurrection," and "To R. B." Marie Howe, "The Star Market" and The Good Thief

John of the Cross, Dark Night of the Soul and Spiritual Canticle

David Jones, The Anathemata and In Parenthesis

Mary Karr, The Liars' Club and Lit

William Langland, Piers Plowman

Philip Larkin, Aubade and The Whitsun Weddings

Denise Levertov, The Stream and the Sapphire and Evening Train

Robert Lowell, Life Studies and The Old Glory

Allen Mandelbaum, translations of The Aeneid and The Divine Comedy

Eugenio Montale, Ossi di seppia and Le occasione

Les Murray, The People's Other World and Fredy Neptune

Wilfred Owen, "Strange Meeting" and "At a Calvary near the Ancre"

Charles Péguy, Jeanne D’Arc and Le Porche du mystère de la deuxième vertu

Alexander Pope, The Rape of the Lock and translations of Iliad and Odyssey

Salvatore Quasimodo, Lirici Greci and La vita non è sogno

Ezra Pound, The Cantos and The Pisan Cantos

Rainer Maria Rilke, Letters to a Young Poet and Duino Elegies

E. A. Robinson, Collected Poems and The Man Who Died Twice

Isaac Rosenberg, "Break of Day in the Trenches" and "On Receiving News of the War"

Christina Rossetti, Goblin Market and Other Poems and The Face of the Deep

Anne Sexton, Live or Die and The Awful Rowing Toward God

William Shakespeare, Hamlet, Macbeth, King Lear, and Sonnets

Robert Southwell, A Child My Choice and The Burning Babe

Wallace Stevens, The Auroras of Autumn and Collected Poems

Francis Thompson, The Hound of Heaven and The Kingdom of God

Chidiock Tichborn, Elegy

Giuseppe Ungaretti, L'Allegria and Vita di un Uomo

Oscar Wilde, The Ballad of Reading Gaol and De Profundis

William Carlos Williams, Spring and All and Paterson (five volumes)

Franz Wright, Walking to Martha's Vineyard and God's Silence

W. B. Yeats, The Second Coming and The Tower

3. Art

Caravaggio, Supper at Emmaus, The Conversion of Saint Paul, and The Taking of Christ Leonardo DaVinci, Last Supper and Saint John the Baptist

Michelangelo, David, frescoes in the Sistine Chapel (Last Judgment, God Creating Adam, and others), Pietà

Luca Signorelli, frescoes of Last Judgment in the Cathedral of Orvieto; Madonna and Child with the Saints
4. Philosophy

Edmund Burke, A Philosophical Enquiry into the Origin of Our Ideas of the Sublime and Beautiful and Vindication of Natural Society

Ralph Waldo Emerson, Self Reliance and Other Essays and Representative Men Jacques Maritain, Integral Humanism and Introduction to Philosophy

Thomas More, Utopia and Dialogue of Comfort Against Tribulation

Blaise Pascal, Pensées and Provincial Letters

Simon Weil, Waiting for God and Letter to a Priest

5. Theology

Abelard, Sic et Non and Theologia 'Summi Boni'

Anselm, Monologion and Proslogion

Thomas Aquinas, Summa Theologiae and Summa Contra Gentiles

Augustine, Confessions and The City of God

Hans Urs von Balthassar, The Glory of the Lord (seven volumes) and Theo-Drama (five volumes)

Catherine of Siena, Treatise on Divine Providence and Prayers

The Cloud of Unknowing

Hildegard of Bingen, Scivias and Liber divinorum operum

Thomas Merton, Seven Storey Mountain and Seeds of Contemplation

Julian of Norwich, Showings

John Henry Newman, Essay on the Development of Christian Doctrine and Apologia Pro Vita Sua

Teresa of Avila, Interior Castle and Life

Thérèse of Lisieux, Story of a Soul

6. History

Thomas Carlyle, The French Revolution: A History and Heroes and Hero Worship Edward Gibbon, The History of the Decline and Fall of the Roman Empire

7. Music

Johann Sebastian Bach, Mass in B Minor, St. Matthew Passion, and St. John Passion

Giovanni Perluigi da Palestrina, Missa sine nomine and Missa Papae Marcelli

8. Video

Robert Barron, Catholicism (at www.wordonfire.org) 